\title{
Claim Study of Contractors in Commercial Berth Project in Duqm Port in Oman
}

\author{
Sultan M.S. Al-Mandhari ${ }^{1}$ and Omar R. Khaleel ${ }^{1 \#}$ \\ ${ }^{1}$ Middle East College, Muscat, Sultanate of Oman \\ \#Advisor
}

\section{ABSTRACT}

The claim during the implementation of projects is very important for the contractor and the consultant. As for the owner, it is considered expensive and cumbersome, and therefore the project contract must be very clear so that there are no gaps or defects against the owner. The aim of this research is to analyze and study deeply contractor's claim. The objectives of this study are to study the main factors for the contractor's claim to the commercial pier project in the Sultanate of Oman, including eleven factors. The second objective is to study the impact of the contractor's claim on the commercial pier project in the Sultanate of Oman, and it includes five factors, as the questionnaire was distributed to customers and various segments of society. The results of analyzing 16 factors to identify the key factors and the impact of the study of the contractors claim conclude that the main factors affecting the contactor's claim to the pier project. The factors and impacts are valid to the study after conducting analysis on the obtained data. The factors include the development unexpected weather conditions, inconsideration of the time frame, government approval of delays, poor coordination with the project parties, poor site management and supervision, a change in the clients requirements, the lack of experienced staff, incompetence among teams, low items in the bill of products, and misunderstanding the scope of work and specifications. The impacts to the completion of the Berth project include payment delays, delays in the extension of time, issuing variation order, value implementation engineering and cost reduction, and contractor's performance.

\section{Introduction}

On behalf of the Sultanate of Oman, the Minister of Finance decided to implement a project inside the port of Duqm, which is a situation or a commercial berth with a length of 2.1 Kilo Metre and width 350 meters. It consists of asphalt roads, five government buildings, and linked to the administration building and the sidewalk operation by Port of Duqm Company (interviewed by Project Engineer).

Meanwhile, Duqm Port Company is the one that operates the port according to the agreement signed with the government of the Sultanate of Oman. It is a Belgian company. The commercial berth project aims to export and import international containers from various countries for use, which is part of the logistics sector (Minister of Transport).

Where the agreement was signed with the contractor, the executor of the project, Turkish Serka Company, Joint Venture with the Portuguese company in November 2016, he started the project in December 2016, as the project duration is thirty-six months preceded by a period of 6 months for Preliminaries Works. The project completion date was in June 2019.

Due to various additional works requested by the user (Duqm Port Company). During the execution of the project, in line with its requirements during the operation of the port, which caused a delay in the completion of the 
project implementation as per the contract. Where the contractor submitted a claim for the implementation of these additional works amounting to three million and six hundred thousand Omani Riyals, moreover, it claims additional period for the implementation of these works is three hundred sixty-five days (One Year) from the original date of project completion from June 2019 until June 2020 (interviewed by Project Engineer). Consequently, the project is late in completion as per the current site.

As per the current situation, Coronavirus is affecting the contractor's progress. The contractor has taken precautions surrounding their labor camp with site works. This issue will also affect the project's milestone. Therefore, it seems that the project progress will finish after the contractor's claim in June 2020. Therefore, this research studys this request deeply, accurately with ensuring the contractor's guarantee and credibility (interviewed Project Engineer). The aim of solving out contractor's issue is to complete the project works as soon as possible and finalize the claim completely. In order to handover the project to the end-user (Duqm Port Company). To expedite his operation as containers works on the project area.

Based on Engineer Mohammed AL Mohsin, in 2012 studied, the contractor "Sarooj Construction Company" implemented a project in the Sultanate of Oman with a total value of more than Five million Omani Riyals, including the project's contingency amount. During the implementation of the project in the late stages of the project, the contractor submitted an extraordinary claim due to changing weather conditions, which caused a delay in the progress of the project work. This crisis occurred for three consecutive months of strong winds throughout the period with a strength of 50 knots per day, which made it difficult for the contractor to complete the work Related to the project, and this event is beyond the control of the contractor (project engineer 2020).

The study did by Wenzhe Tan in 2017. It summarized the reasons for the claims of international contractors for engineering, building, and construction projects and about their importance. In addition, when they implemented, especially in complex and technical projects with the need of international contractors with experience. So, they implemented against the contractor in light of them. The project designed according to the conditions agreed with the client and implementation, supply, and installation of project equipment. Thus, the contractor responsible for the whole of the project from beginning to the End-stage (Wenzhe Tan 2017). Through this study, the author mentioned a live project on the execution of a construction project.

As per the author, William Vidogah, in 1997, stated that there are a large number of disputes arising over construction contract claims, and the concept of its expansion is increasing every day. A less there is a project and the presence of gaps that are exploited by the contractor in the project whenever an opportunity is provided for the contractor to request a claim.

These claims are managed by practical life and not administrative, so they must have a unified and global system for these claims, and this is what the author sought to discover the shortcomings and their causes in the practice of managing claims. Administrative and technical affairs of the project and to know how to pay the amounts of the claims, if they are right.

Improving Management of Claims study surveyed a postal questionnaire that was prepared with the aim of identifying practical management problems and constraints related to passing, preparing, and assessing claims. This investigation called four main areas for claim management, namely (Thomas et aI. (1994):

1. Aspects of preparing claims that impede the contractor

2. Responsibility for the contract claims management function

3. Claims documentation problem

4. Aspects of determining the potential amount to result in disputes

The study also stated that a postal survey was conducted with interviews with ten contracting companies and consultancy case studies, claims on five projects aimed at clarifying some of the issues raised by the results of the literature review and survey (Bosche 1978). 
200 questionnaires sent to UK contractors, 69 of the 61 returned correctly, the response rate of about $32 \%$, broad breakdown respondents.

The study was conducted by the author Mohammed S. Hashem M. Mehany in 2014 for his doctoral study, and this study aimed to evaluate and analyze the causes and effects of these claims on road and bridge projects and create an effective claim management system. This study was carried out on road construction projects and was limited only to projects in which a delivery-bid-building system was used.

Also, This study examined the factors of leadership that lead to allegations such as the extent to which they are affected and how this information affects them, the mechanism of working methods for estimating and analyzing costs and claims for delay, what are the most important elements of cost and resources with regard to claims arising from the delay of the DBB contracts, how can a system be established My job is to manage claims at the lowest level and how this system can be handled in DBB contracts (Mehany, Mohammed S. Hashem M 2014)

Sometimes there are problems in construction contracts, when there are ambiguities or deficiencies in terms of the tender contract so that the documents are incomplete, which causes risks in the project from the contractor or consultant's claim to the project, especially some of the claims that exaggerate the work, which occurs conflict with the owner and a misunderstanding between the two parties remains (Rubin, Fair weather, Guy, \& Maevis 1992).

In the event that the dispute between the two parties is not resolved, the first party, the contractor, shall request a request for clarification and clarification in the judicial system in the form of a claim. The claim is that one of the parties from the owner or contractor claims money, time, quality, and safety for the benefit of the workers that he implemented on the site versus the direction of the other party, with the aim of claiming money or time (Barnard 2005).

\section{Methods and Design}

Claims are a vital topic in the field of construction management. Claims occur during project implementation, and try to avoid them. They are related to construction and other components of time, cost, and quality. The claims are also related to psychological factors since the claim is part of the conflict that takes place in the projects between the project parties (owner, contractor, consultant). After the completion of the project proposal, further research was conducted to increase my understanding of the field. Numerous studies were conducted to match my research project information requirements.

After the completion of the literature review relevant to this study, the research methodology was drafted. The research methodology provides the researchers with the intended path to follow to acquire accurate statistical inferences that are sought after in the research objectives (Sileyew 2019). A properly designed research methodology provides an appropriate framework from which the analysis is conducted.

A good research methodology not only satisfies the research quality criteria for the conducted literature review but also provides an accurate feature of the analysis to make it stand out(Snyder 2019). This chapter, therefore, provides an in-depth approach to the methods of data collection used to draw an accurate analysis of the information collected in the research. The sequence to the research was conducted by first developing the research project, conducting studies relevant to the study, developing the research methodology appropriately, developing the quantitative research design, and finally developing a questionnaire based on experience from a previous and related study. 


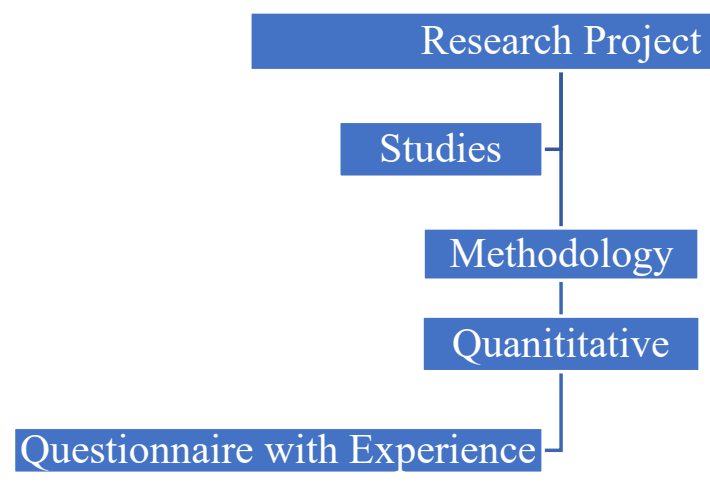

Figure 1. Project Flowchart

The research methodology provides a guide to the preferred methods for researching by explaining the data collection methods followed, the statistical methods followed. To achieve the objectives set for this research, namely to identify the factors affecting the claim to the pier commercial project and the impact of the contractor's claim to the Berth project, quantitative analysis is selected as the best research methodology. Qualitative studies provide research with first-hand experience in the research study. This provides robust data that provides the researcher with information that is reliable and valid. The data obtained in the research is faced with numerous challenges, such as the confidentiality of critical project information.

This research methodology follows guidelines that ensure that the information collected is restricted to the research study and does not breach or violate the research ethics of confidentiality.

\subsection{Quantitative method}

Quantitative research is a method concerned with the collection and analysis of the data in a structured format, and it is usually represented in a numerical format. The critical objective of this type of research method revolves around the design of accurate and reliable measurements that provide an accurate ground for statistical analysis (Goertzen 2017). The focus of this method is in answering the inquisitive of how or what the research fulfills. The quantitative methodology begins with the determination of the study hypothesis, which proceeds with the use of descriptive statistics. The hypotheses to the study are, how well did the factors affect the claim to the commercial pier project in Oman, and what is the intensity of the impacts to the contractor's claim on the commercial pier project in the sultanate of Oman.

The adopted quantitative research methodology adopted in this research involves the use of questionnaires as the primary data collection technique. The questionnaire is structured and is composed of a set of closed questions that are based on a range of agreement and the degree of impact. The questions are further analysed using the Statistical Package for social sciences (SPSS).

\subsection{Questionnaire Design}

A questionnaire is a consolidation of questions that are aimed at obtaining the research participants opinion on the questions (Roopa and Rani 2012). The selected type of questionnaire follows a closed-ended survey structure. The questionnaire design phase is critical to the completion of the questionnaire since it captures the requirements of the study and assimilates them into a well structure data collection material. The questionnaire design starts with the initial consideration of the research objectives whereby a critical analysis is performed to evaluate the depth required in the study. Once completed, the question contents are listed and the questions are phrased according to the required 
appropriate format. The sequence of the question is then evaluated, and the questionnaire is tested to identify the fitness of the questions to the study. Once the questionnaire fitness is approved, the final questionnaire is produced and provided to the research participants.

The questionnaire design for this study includes two types of Likert scales rated from 1-5. The first type evaluates the agreement to the question whereby 1 represents a Strongly disagree decision, 2 shows a disagree option, 3 shows a neutral decision, 4 represents Agree, and 5 shows Strongly agree. The other scale evaluated the impacts where 1 represents No Impact with increment as the values increase until 5 represents a very high impact.

Prior to the beginning of the actual analysis, the validity of the questions to the study is evaluated to identify if the questions are a proper fit for the study. A validity test is performed to obtain accurate information concerning the study by obtaining the Cronbach's alpha value for research variables. The research included a total of 55 samples from the field on construction. The validity of the factors to satisfying the questions related to the topic under study is $89.7 \%$. This indicates that the research questions will answer the research objectives by $89.7 \%$, which is summarized by the tables below.

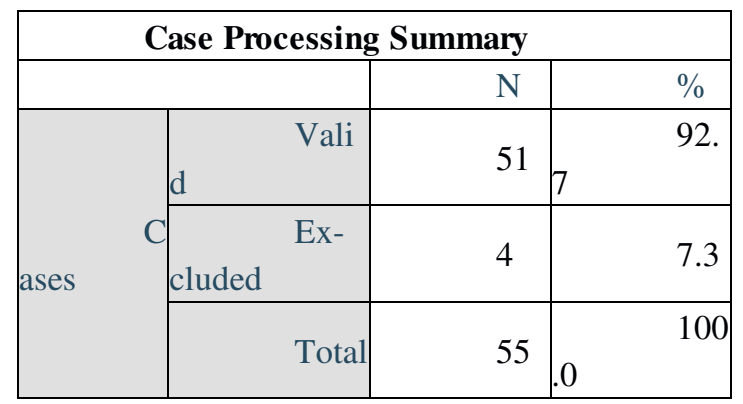

\begin{tabular}{|l|l|l|}
\hline \multicolumn{2}{|l|}{ Reliability Statistics } \\
\hline Cronbach's Alpha & $\begin{array}{l}\text { Cronbach's Alpha Based on } \\
\text { Standardized Items }\end{array}$ & N of Items \\
\hline 0.897 & 0.893 & 17 \\
\hline
\end{tabular}

\subsection{Sampling}

The sampling technique used in this study follows a simple random technique coupled with the purposive sampling techniques are used to select the research participants in Duqm's construction management sector. To select the representation from the sector, a combination of supervisors, clients, design engineers, and contractors were selected as the sector. From a population size of 150, the sampling frame was determined using the formula below.

$$
\text { Sample size }=\frac{\frac{z^{2} \times p(1-p)}{e^{2}}}{1+\left(\frac{z^{2} \times p(1-p}{e^{2} N}\right)}
$$

Where $\mathrm{N}=$ population size, 150

$\mathrm{e}^{\mathrm{x}}=$ margin of error

$\mathrm{Z}=\mathrm{z}$ score 
From the above formula, the number of required respondents is 55 from a population of 150 at a $95 \%$ significance level and a margin of error of $10 \%$.

\subsection{Quantitative Analysis}

In this study, the quantitative analysis aims to provide a suitable answer to the research objectives. The analysis identifies the factors affecting the claim to the commercial pier project in Oman. These factors are directly involved in the acceptance or denial of the pier project. The impact of the identified factors on the contractor's claim on the Berth project is also evaluated since they pose a threat to the completion of the project according to the designed time frame.

The preferred methodology of analyzing the impact of the factors is using SPSS since it is designed to analyse data in numeric form and word form. To conclude the obtained data, descriptive statistics of each factor are obtained, and the factors are categorically evaluated based on the response. From the descriptive statistic, the percentage majority with the response determines the impact the factor poses to the claim to the project.

The factor is evaluated in two forms, which identify the categorical impact of the factors based on the agreement scale with the item with the most Strongly agreeing respondents, and the largest percentage of respondents in that section then makes up the respondents. The listing proceeds further as the agreement scale proceeds to the strongly disagreeing with the smallest percentage among the respondent's factors is listed last. The same criteria are used to categorize the impacts of the study.

\section{Data Analysis and Presentation}

\subsection{Introduction}

This chapter discusses the results of the questionnaire administered to the employees in the construction sector. This chapter provides further insight into the data analysis procedures and techniques used to draw statistical inferences regarding the data collected. The analysis follows a descriptive approach that aims to identify the key factors affecting the claim to the commercial pier project and the impact study of the contractor's claim for the commercial berth project in Oman.

\subsection{Questionnaire Analysis}

The research was conducted within the construction sector equally distributed across the private sector and the government sector. The questionnaire was divided into three parts, namely, the respondent's general information, the key factors affecting the claim to the commercial pier project in Oman, and the final part tests for the impact study of the contractor's claim for the berth project in Oman.

The general information comprises of the gender of the respondents, the nationality, the age, the level of education, their position in the firm, the years of working experience, their position in the construction field, and the procurement strategy in the project. The factors studied include the unexpected weather conditions involved in the projects, the scope of work, and the specifications, among others. Some of the impact factors discussed in the third chapter include the delay in payments, the delay extension of time, the issuing variations in projects, value implementation in engineering and cost reduction, and the contractor's performance.

The questionnaire was distributed among the user using social media and e-mail links to get the maximum respondents. The overall respondents received were fifty-five. 


\section{Question 1. What is your Gender?}

From the 55 respondents, 14 were female, and 41 were male with an equivalent percentage distribution of $25.5 \%$ for the females and $74.5 \%$ for the male, as illustrated in table 1 below.

Table 1: Gender representation of the respondents

\begin{tabular}{|c|c|c|c|c|c|}
\hline \multicolumn{6}{|c|}{ Gender } \\
\hline & & quency & cent $\quad$ Per & $\begin{array}{l}\text { Valid } \\
\text { Percent }\end{array}$ & \begin{tabular}{|l} 
Cumula- \\
tive Percent
\end{tabular} \\
\hline \multirow{3}{*}{ alid } & male $\mathrm{Fe}$ & 14 & 25. & 25.5 & 25.5 \\
\hline & ale $\quad$ M & 41 & 74. & 74.5 & 100.0 \\
\hline & $\begin{array}{ll} & \mathrm{T} \\
\text { otal } & \end{array}$ & 55 & 100 & 100.0 & \\
\hline
\end{tabular}

\section{Question 2. What is your nationality?}

The nationality of the working employees in Oman is distributed across the Omani and the Non-Omanis. $9.1 \%$ of the respondents were non-Omani, while $90.9 \%$ were Omani respondents, as illustrated in table 2 below.

Table 2: The Nationality of the respondents

\begin{tabular}{|c|c|c|c|c|c|}
\hline \multicolumn{6}{|c|}{ Nationality } \\
\hline & & \begin{tabular}{|l} 
Fre- \\
quency
\end{tabular} & $\begin{array}{ll} & \text { Per } \\
\text { cent } & \\
\end{array}$ & Percent & \begin{tabular}{|l} 
Cumula- \\
tive Percent
\end{tabular} \\
\hline \multirow{3}{*}{ alid } & Omani & 5 & 9.1 & 9.1 & 9.1 \\
\hline & i Oman & 50 & 90 & 90.9 & 100.0 \\
\hline & Total & 55 & 0.0 & 100.0 & \\
\hline
\end{tabular}

\section{Question 3. How old are you?}

The age distribution was composed of three age groups whereby 13 respondents making up $23.6 \%$ were between 18 and 30 years old, 41 respondents making up 74.5\%, were between 31 and 45 years old, and only one respondent, equivalent to $1.8 \%$, was in the 46 to 60 years age group as illustrated in table 3 below.

Table 3: The Age distribution of the respondents

\begin{tabular}{|c|c|c|c|c|c|}
\hline \multicolumn{6}{|c|}{ Age } \\
\hline & & quency & cent & $\begin{array}{l}\text { Valid } \\
\text { Percent }\end{array}$ & \begin{tabular}{|} 
Cumula- \\
tive Percent
\end{tabular} \\
\hline alid & to $30 \quad$ From 18 & 13 & 6 & 23.6 & 23.6 \\
\hline
\end{tabular}




\begin{tabular}{|c|c|c|c|c|}
\hline to $45 \quad$ From 31 & 41 & 5 & 74.5 & 98.2 \\
\hline to $60 \quad$ From 46 & 1 & 1.8 & 1.8 & 100.0 \\
\hline Total & 55 & 0.0 & 100.0 & \\
\hline
\end{tabular}

\section{Question 4. What is your level of Education?}

The level education of the respondents was distributed among Master degree graduates who made up 30.9\% of the respondents, and secondary school graduates made up 3.6\% of the total respondents, with the Degree graduates making up $65.5 \%$. Table 4 below identifies the frequency and percent of the respondents.

Table 4: The level of education of the respondents

\begin{tabular}{|c|c|c|c|c|c|}
\hline \multicolumn{6}{|c|}{ Level of Education } \\
\hline & & quency & \begin{tabular}{|ll} 
cent & Per \\
\end{tabular} & \begin{tabular}{|l|} 
Valid \\
Percent
\end{tabular} & \begin{tabular}{|l} 
Cumula- \\
tive Percent
\end{tabular} \\
\hline \multirow{4}{*}{ alid } & ter & 17 & 30. & 30.9 & 30.9 \\
\hline & $\begin{array}{ll}\text { Sec- } \\
\text { ondary }\end{array}$ & 2 & 3.6 & 3.6 & 34.5 \\
\hline & versity & 36 & 65. & 65.5 & 100.0 \\
\hline & Total & 55 & 100 & 100.0 & \\
\hline
\end{tabular}

\section{Question 5. What is your position in your firm?}

The positions are made up of engineers, medical doctors, officers, teachers, and other professions. Engineers make up $72.7 \%$ of the respondents. $1.8 \%$ of the respondents were medical doctors, $5.5 \%$ were officers, $3.6 \%$ were teachers, and other professions made up $16.4 \%$ of the total respondents, as illustrated in table 5 below.

Table 5: The positions held in the firms

\begin{tabular}{|c|c|c|c|c|c|}
\hline \multicolumn{6}{|c|}{ Position in the firm } \\
\hline & & Fre- & Per & Valid & Cumulative \\
\hline & & quency & cent & Percent & Percent \\
\hline \multirow{4}{*}{ alid } & Engineer & 40 & 72. & 72.7 & 72.7 \\
\hline & Doctor & 1 & 1.8 & 1.8 & 74.5 \\
\hline & Officer & 3 & 5.5 & 5.5 & 80.0 \\
\hline & Others & 9 & 16. & 16.4 & 96.4 \\
\hline
\end{tabular}




\begin{tabular}{|l|l|l|l|l|l|}
\hline & Teacher & 2 & 3.6 & 3.6 & 100.0 \\
\cline { 2 - 6 } & Total & 55 & 10 & 100.0 & \\
\hline
\end{tabular}

\section{Question 6. How many years of working experience do you have?}

The working experience of the respondents varies from a year to more than 15 years, as illustrated in table 6 below. 10 respondents were in the experience bracket of 1 to 5 years, 17 respondents made up 29.3\% of the respondents, 19 participants had 11 to 15 years of experience constituting $32.8 \%$, the majority, and only 9 respondents had more than 15 years of experience which amounted to $15.5 \%$ percent.

Table 6: The years of working experience of the respondents

\begin{tabular}{|c|c|c|c|c|c|}
\hline \multicolumn{6}{|c|}{ Years of working experience } \\
\hline & & quency & cent $\quad$ Per & $\begin{array}{l}\text { Valid } \\
\text { Percent }\end{array}$ & \begin{tabular}{|l} 
Cumula- \\
tive Percent
\end{tabular} \\
\hline \multirow{5}{*}{ Valid } & $1-5$ years & 10 & 17. & 18.2 & 18.2 \\
\hline & years $\quad 6-10$ & 17 & 29. & 30.9 & 49.1 \\
\hline & years $11-15$ & 19 & 32. & 34.5 & 83.6 \\
\hline & years $\quad$ Above 15 & 9 & 15. & 16.4 & 100.0 \\
\hline & Total & 55 & 94. & 100.0 & \\
\hline Total & & 55 & 0.0 & & \\
\hline
\end{tabular}

\section{Question 7. What is your position in the construction field?}

The construction industry in Oman is made up of clients, contractors, supervisors, and design engineers. $45.5 \%$ are clients, contractors make up 18.2\%, design engineers make up 12.7\%, supervisors(consultants) make up $14.5 \%$ of the total population. Some positions are held by clients, contractors, supervisors, and design engineers who make up $1.8 \%$ of the industry, while the remaining 3.6\% constitute clients and supervisors. Figure 7 below illustrates the major positions held by the individuals in the construction field.

Table 7:The position of the individuals in the industry

\begin{tabular}{|c|c|c|c|c|c|}
\hline \multicolumn{6}{|c|}{ Position in the construction field } \\
\hline & & quency & cent & $\begin{array}{l}\text { Valid } \\
\text { Percent }\end{array}$ & \begin{tabular}{|} 
Cumula- \\
tive Percent
\end{tabular} \\
\hline & & 2 & 3.6 & 3.6 & 3.6 \\
\hline alid & Client & 25 & 45 . & 45.5 & 49.1 \\
\hline
\end{tabular}


Middle East College

\begin{tabular}{|c|c|c|c|c|}
\hline $\begin{array}{l}\text { Client; Contractor; } \\
\text { Supervision (Consultant); De- } \\
\text { sign Engineer }\end{array}$ & 1 & 1.8 & 1.8 & 50.9 \\
\hline $\begin{array}{l}\text { Client; Supervision } \\
\text { (Consultant) }\end{array}$ & 2 & 3.6 & 3.6 & 54.5 \\
\hline Contractor & 10 & 18. & 18.2 & 72.7 \\
\hline Design Engineer & 7 & 12. & 12.7 & 85.5 \\
\hline \begin{tabular}{|l} 
Supervision (Con- \\
sultant)
\end{tabular} & 8 & 5 & 14.5 & 100.0 \\
\hline Total & 55 & $0.0 \quad 10$ & 100.0 & \\
\hline
\end{tabular}

\section{Question 8. What is the procurement strategy used in your project?}

Procurement strategies consist of construction management, with a 7.3\% percent representation. Engineering, procurement, and contracting constitute $32.7 \%$ of the total. The combination of engineering, procurement and contracting, project management, and construction management makes up $1.8 \%$ of the incorporated strategies. $9.1 \%$ combine the engineering, procurement and contracting, and the traditional procurement approach. $10.9 \%$ use the project management procurement strategy, while $36.4 \%$ use the traditional procurement strategy. Only $1.8 \%$ use the combination of traditional and construction management approaches, as illustrated in table 8 below.

Table 8: The various procurement strategies in the project.

\begin{tabular}{|c|c|c|c|c|c|}
\hline \multicolumn{6}{|c|}{ Procurement strategy in the project } \\
\hline & & quency & Per $\left.\right|_{P}$ & \begin{tabular}{|l} 
Valid \\
Percent
\end{tabular} & \begin{tabular}{|l} 
Cumula- \\
tive Percent
\end{tabular} \\
\hline \multirow{6}{*}{ alid } & \begin{tabular}{|l} 
Construction Man- \\
agement
\end{tabular} & 4 & 7.3 & 7.3 & 7.3 \\
\hline & $\begin{array}{l}\text { Engineering, Pro- } \\
\text { curement and Contracting }\end{array}$ & 18 & 32. & 32.7 & 40.0 \\
\hline & $\begin{array}{l}\text { Engineering, Pro- } \\
\text { curement and Contracting; } \\
\text { Project Management; Con- } \\
\text { struction Management }\end{array}$ & 1 & 1.8 & 1.8 & 41.8 \\
\hline & $\begin{array}{l}\text { Engineering, Pro- } \\
\text { curement and Contracting; } \\
\text { Traditional }\end{array}$ & 5 & 9.1 & 9.1 & 50.9 \\
\hline & Project Management & 6 & 10. & 10.9 & 61.8 \\
\hline & Traditional & 20 & 36. & 36.4 & 98.2 \\
\hline
\end{tabular}




\begin{tabular}{|c|c|r|r|r|r|}
\hline $\begin{array}{c}\text { Traditional; Con- } \\
\text { struction Management }\end{array}$ & 1 & 1.8 & 1.8 & 100.0 \\
\hline \multirow{2}{*}{ Total } & 55 & 10 & 100.0 & \\
\hline
\end{tabular}

\subsection{Results and discussion of the Questionnaire findings}

The findings of the questionnaire are divided into two major categories, namely the factors affecting the claim to the pier project in Oman and the impact of the contractor's claims for the commercial berth project in Oman.

\subsubsection{Key factors affecting the claims to the commercial pier project in Oman}

\section{Question 9. Unexpected weather conditions.}

Out of the 55 participants who participated in this study, $40 \%$ neither disagree nor agree that the unexpected weather conditions were the major cause of affecting the selection of the pier project.

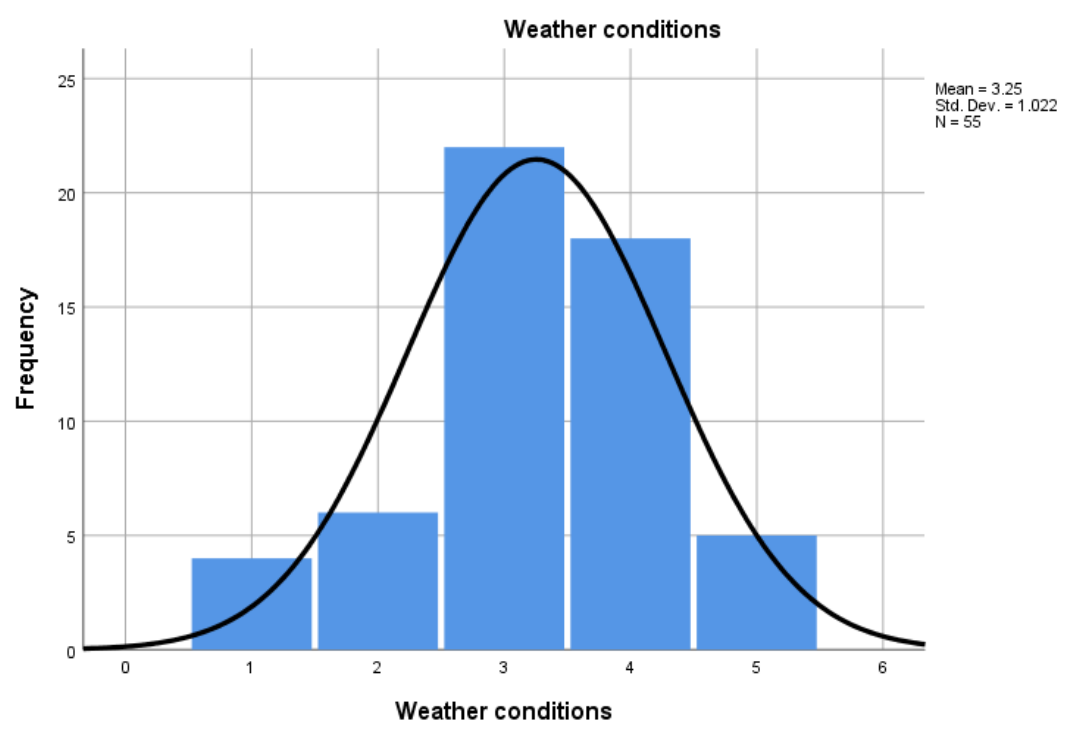

Figure 2: Graph representing the perception on weather condition

(1-Strongly Disagree, 2-Disagree,3-Neutral, 4-Agree,5-Strongly Agree)

However, a significant $32.7 \%$ of the participants agreed with only $9.1 \%$ strongly agree with the infrequent weather as a cause. $10.9 \%$ disagree, while $7.3 \%$ strongly disagreed with the reason for selecting the strategy, as illustrated in table 9 above.

Question 10. Misunderstanding the scope of work and specifications 
$45.5 \%$ of the respondents agree that the scope of work is a contributing factor. $18.2 \%$ disagree and fail to hold the factor responsible for the decision, while $14.5 \%$ strongly agree on the accountability of the factor to the development. $12.7 \%$ has a neutral stand on the factor, while $9.1 \%$ strongly disagree, as summarized by table 10 below.

(1-Strongly Disagree, 2-Disagree,3-Neutral, 4-Agree,5-Strongly Agree)

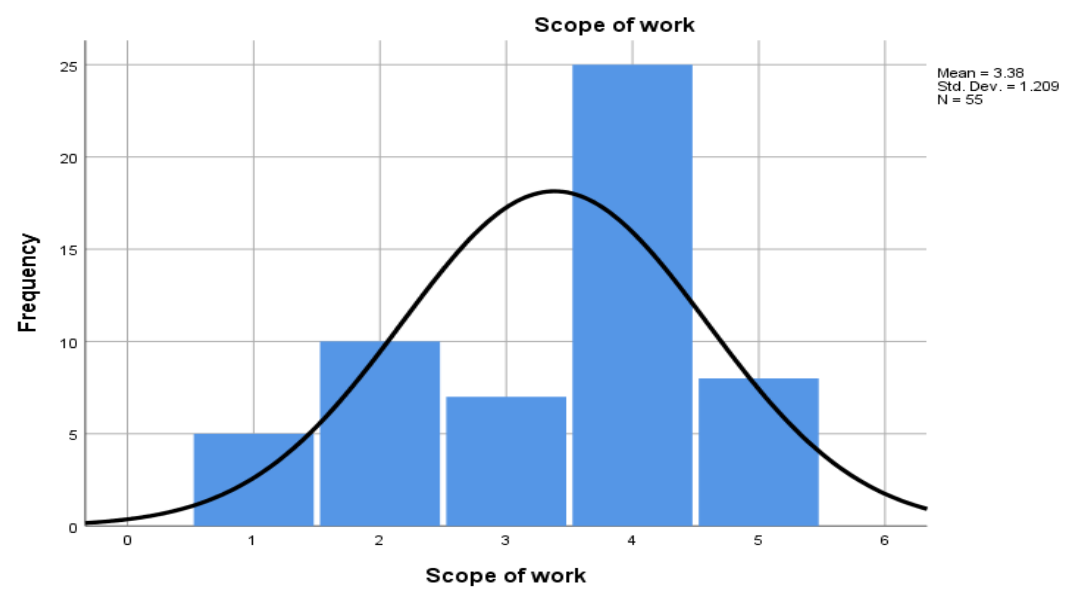

Figure 3: Histogram showing the perception about the scope of work

Question 11. Low items prices in the bill of quantity

$50.9 \%$ of the participants agree that the low-price items are a major contributor to the pier project. $20 \%$ consequently disagree, $14.5 \%$ have neither disagree nor agree on the low prices being one of the contributors to claim to the pier project. $10.9 \%$ of the respondents strongly agree on the use of low prices as a contributor, while $1.8 \%$ of the respondents strongly disagreed. One of the respondents did not think of low-price items as a suitable determiner to the strategy, as illustrated in table 11 below.

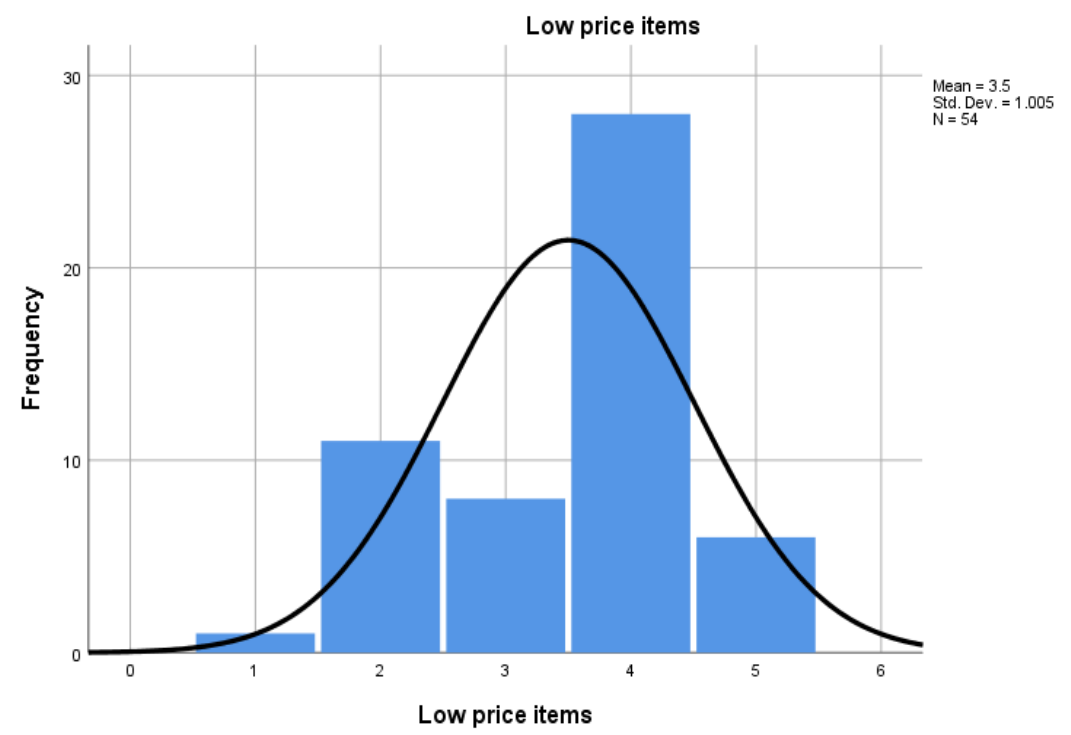

Figure 4: Histogram for the low-price items' decisions 


\section{(1-Strongly Disagree, 2-Disagree,3-Neutral, 4-Agree,5-Strongly Agree)}

Question 12. Incompetent project team on the site

$40 \%$ of the respondents agree on incompetence as a contributing factor. $23.6 \%$ were neither confirmed nor selected incompetence of the project teams as a contributor. $20 \%$ disagree on the factor being a contributor, while $12.7 \%$ strongly agree, making incompetence a factor causing the decisiveness in the selection pier project.

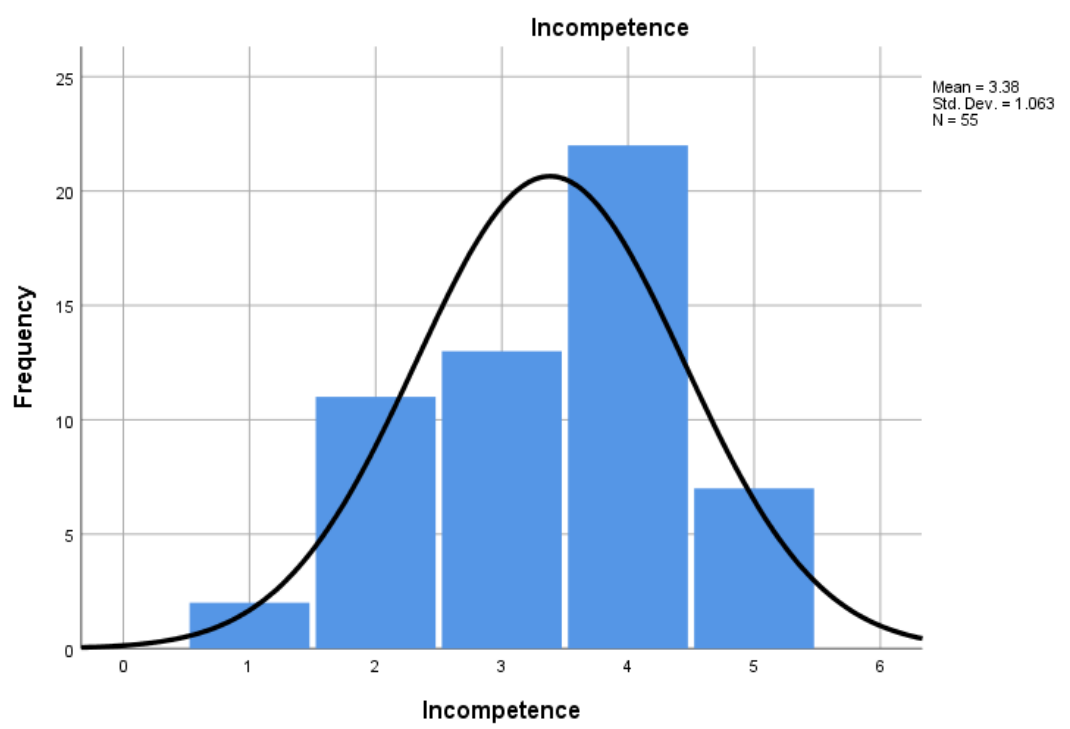

Figure 5: Graphed decision of the incompetent project team on the site

(1-Strongly Disagree, 2-Disagree,3-Neutral, 4-Agree,5-Strongly Agree)

Only $3.6 \%$ of the respondents strongly disagreed with the incompetence of the project team as a contributing factor.

Question 13. Lack of staff experienced

Among the group of respondents, $38.2 \%$ agree that the lack of experienced staff contributed to the claim to the commercial pier project. $21.6 \%$ neither agreed nor disagreed with s neutral decision while $18.2 \%$ of the respondents strongly agreed, while $16.4 \%$ disagreed that the lack of experienced staff is a major contributor to the claim to the pier project in Oman. 


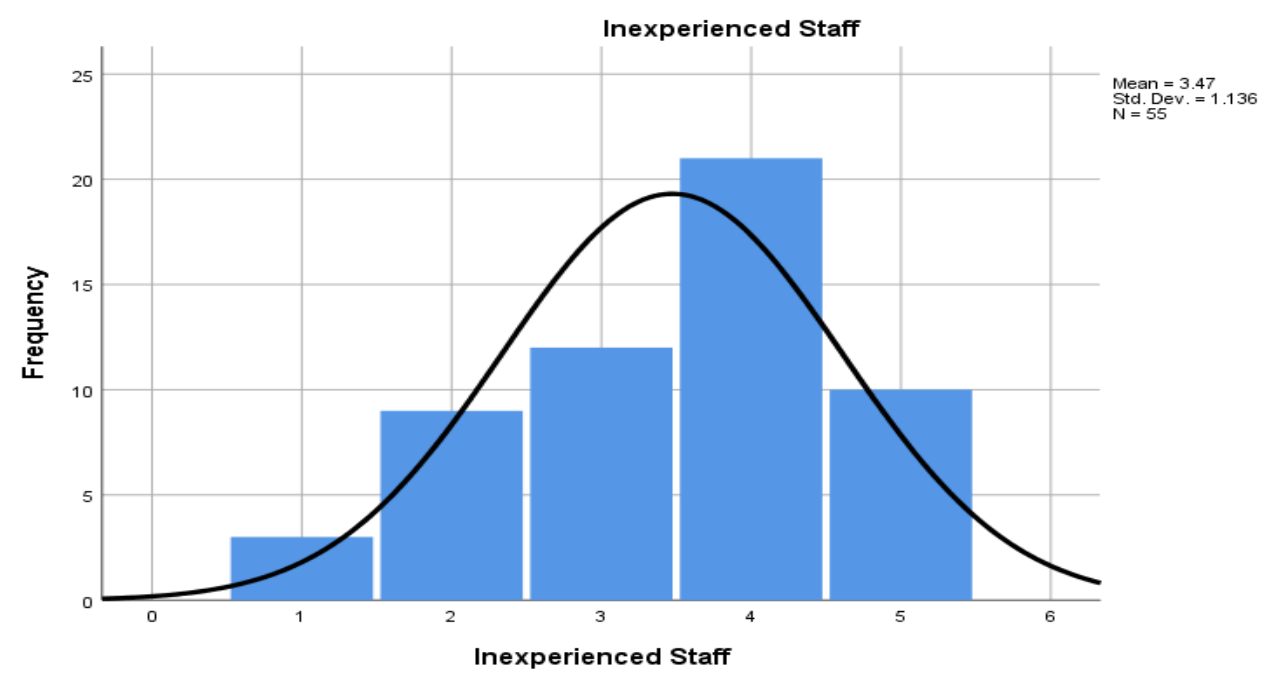

Figure 6: Histogram showing the lack of experienced staff decisions

(1-Strongly Disagree, 2-Disagree,3-Neutral, 4-Agree,5-Strongly Agree)

Only $5.5 \%$ of the respondents strongly disagreed with the argument of inexperienced staff being the primary reason behind the claim to the pier project in Oman, as identified in table 13 above.

Question 14. Clients change requirements

$54.5 \%$ of the respondents agree that the client's change in requirements is a determiner in the adoption pier project. A corresponding $21.8 \%$ of the respondents strongly agree that a changing requirement is an adequate determiner. $14.8 \%$ had a neutral stand on the matter, while $7.3 \%$ disagreed with the argument. Only $1.8 \%$ of the respondents strongly disagreed with the argument.

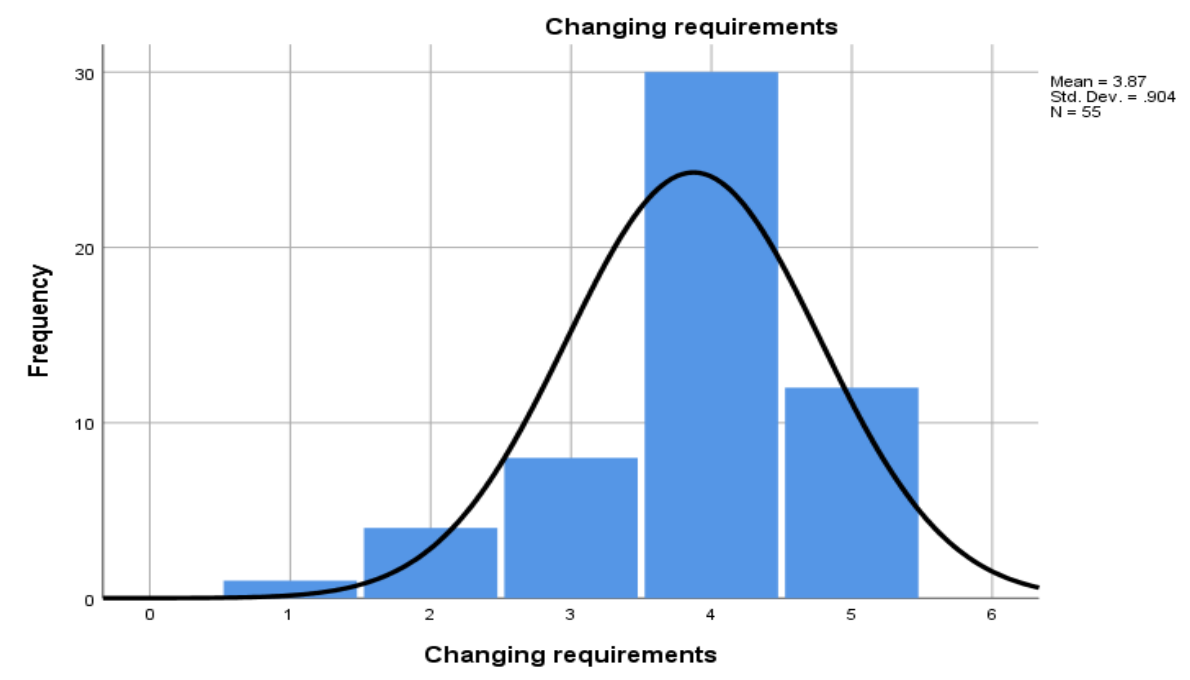

Figure 7: Frequency distribution of the client's change in requirements

(1-Strongly Disagree, 2-Disagree,3-Neutral, 4-Agree,5-Strongly Agree)

Question 15. Contractors poor site management and supervision 
A $36.4 \%$ majority of the respondents strongly agree with the argument that the contractor's poor site management and supervision is a significant cause in the selection of the pier project. $21.8 \%$ of the respondents strongly agree, while a corresponding $21.8 \%$ have made a neutral decision on the matter. Only $9.1 \%$ of the respondents strongly disagree, while a $10.9 \%$ representation argues to disagree. Table 15 below summarizes the respondents' arguments.

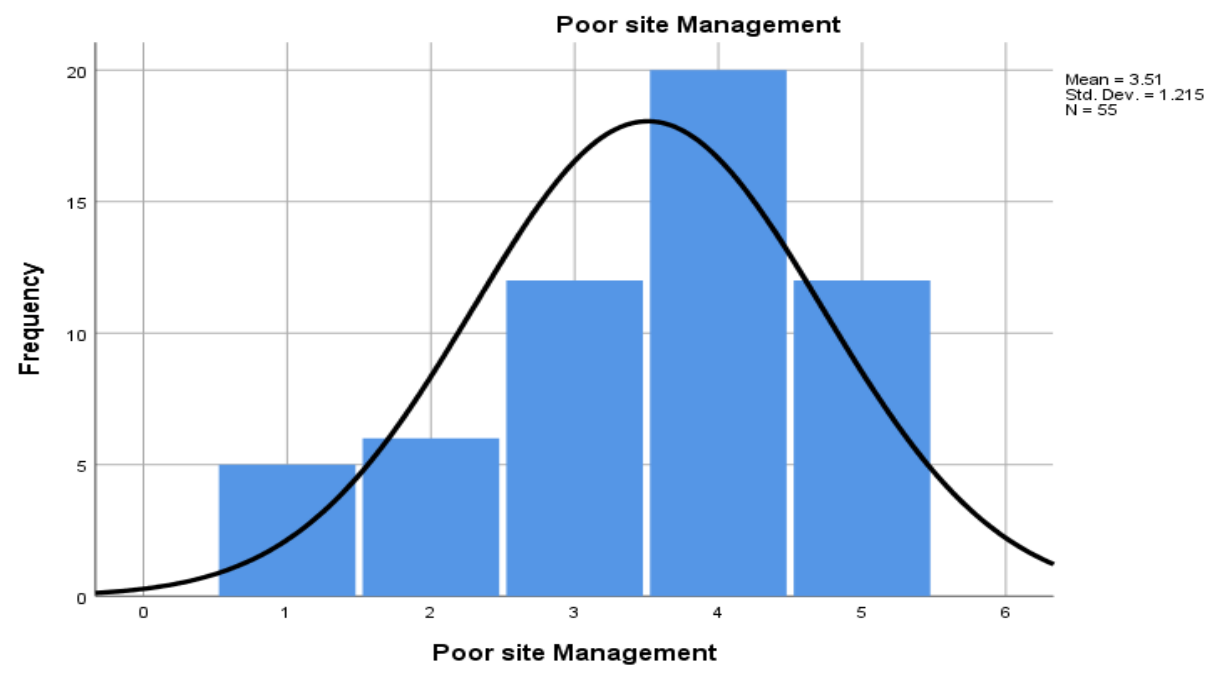

Figure 8: Frequency distribution of the contractors poor site management and supervision decisions

(1-Strongly Disagree, 2-Disagree,3-Neutral, 4-Agree,5-Strongly Agree)

\section{Question 16. coordination with Project's parties Poor}

$43.6 \%$ of the respondents agree that poor coordination significant contributor to the strategy. A corresponding $16.4 \%$ disagree and strongly agree that poor coordination is a sufficient determiner in the selection of the strategy. $14.5 \%$ of the respondents have a neutral argument, with only $9.1 \%$ strongly disagreeing with the argument. These findings are summarized in table 16 below.

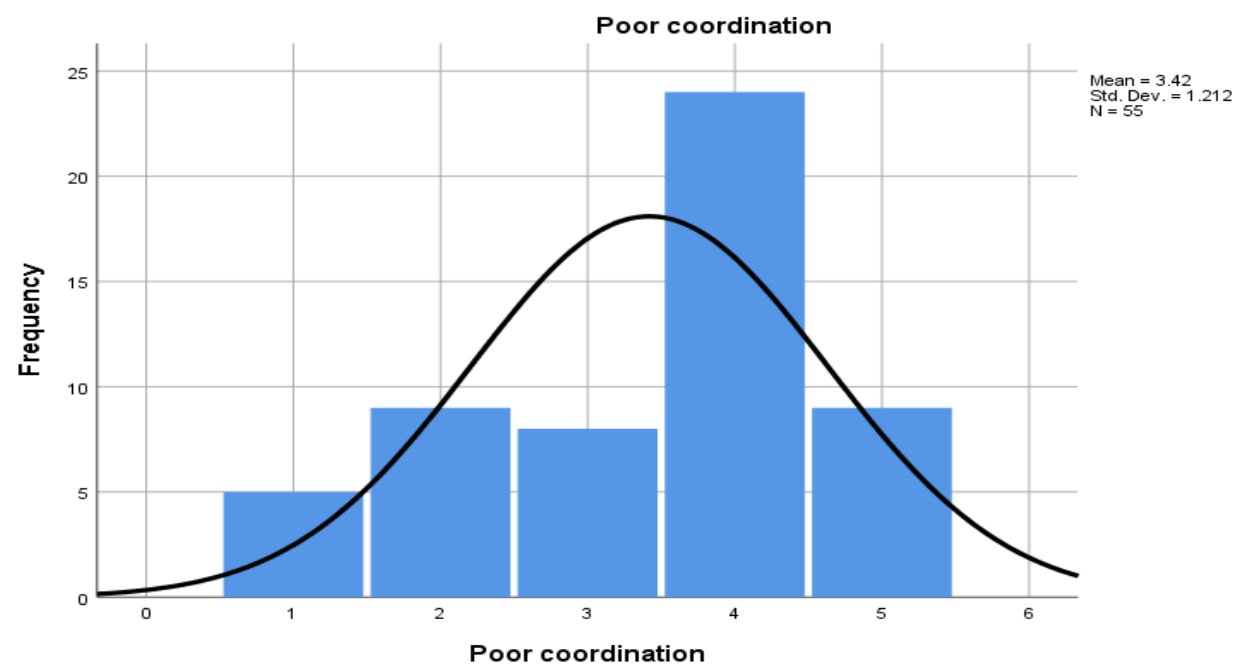

Figure 9: Poor coordination with project parties

(1-Strongly Disagree, 2-Disagree,3-Neutral, 4-Agree,5-Strongly Agree) 


\section{Question 17. Government authorities approval be a delay}

$45.5 \%$ of the respondents agree that delays from the government authorities are a major contributor to the strategy. $18.2 \%$ of the respondents are neutral on the matter, while $16.4 \%$ strongly agree on the factor being a major contributor. $12.7 \%$ of the respondents strongly disagree, while $7.3 \%$ of the respondents disagree that government authorities' approval is a sufficient determiner, as summarized by table 17 below.

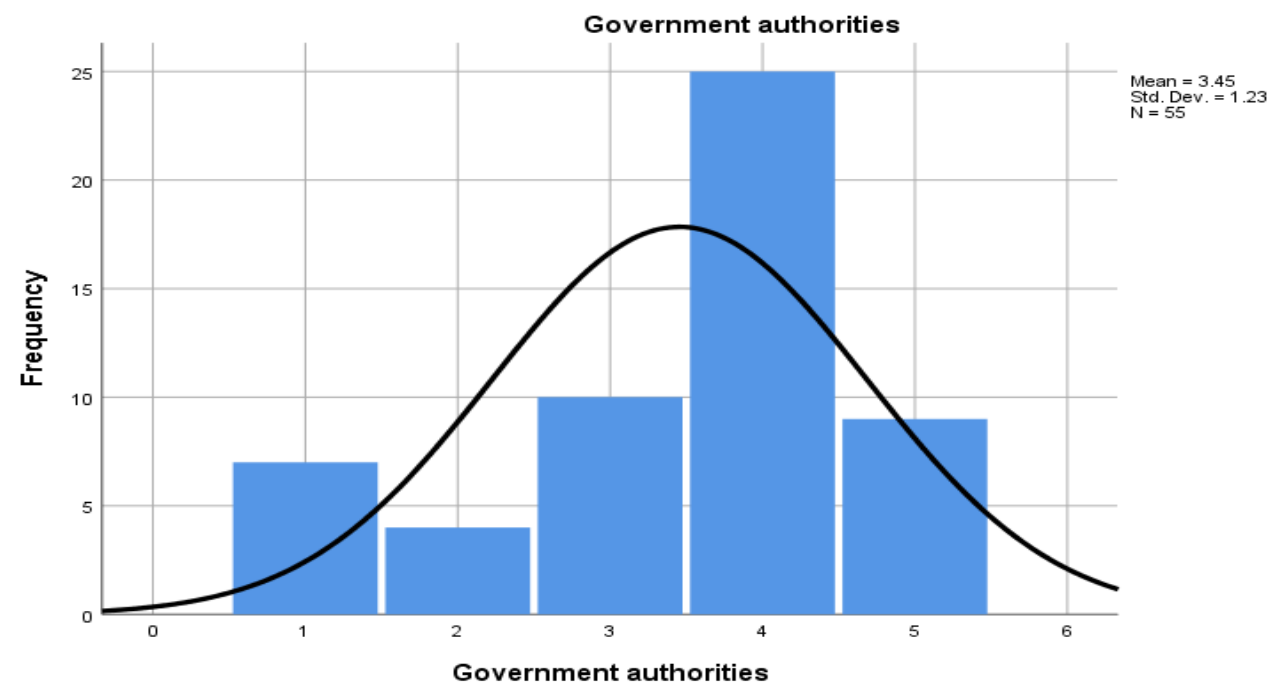

Figure 10: The frequency distribution of the government authorities approval delay arguments

(1-Strongly Disagree, 2-Disagree,3-Neutral, 4-Agree,5-Strongly Agree)

\section{Question 18. The project frame time is not considered}

Twenty-one participants agreed that the project time frame is a contributor to the claim of the pier project. 13 respondents representing $23.6 \%$ of the participants in the study, have a neutral decision on the matter. $21.8 \%$ disagree that a project's time frame is the reason behind the selection of the pier project, while $10.9 \%$ strongly agree and a corresponding 3.6\% disagreeing strongly on the matter. One of the respondents did not view the time frame as a factor, as summarized by table 18 below. 


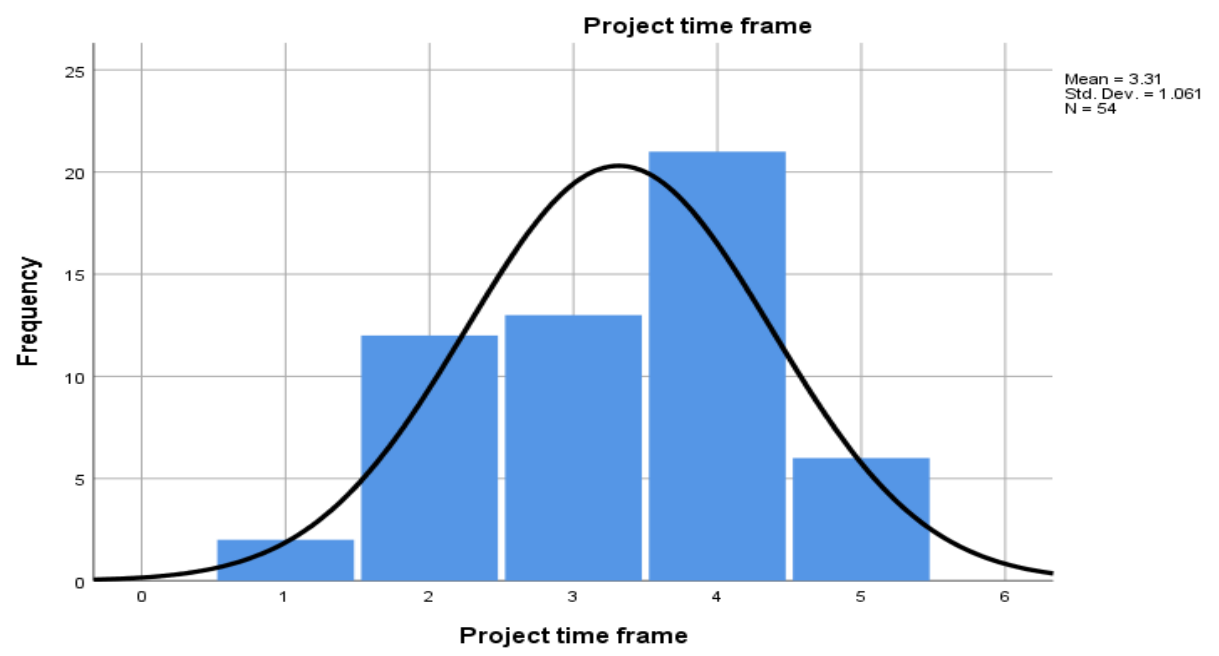

Figure 11: A histogram summarizing the frequency distribution of the project time frame

(1-Strongly Disagree, 2-Disagree,3-Neutral, 4-Agree,5-Strongly Agree)

\section{Question 19. Contractor's greed of spending contingency amount allocated for the project}

$32.7 \%$ of the respondents strongly agreed that the contractor's greed plays a vital role in the selection of the pier project. A significant $29.1 \%$ had a neutral standing on the matter, with $16.4 \%$ strongly agreeing on the matter. $12.7 \%$ of the respondents disagreed on the matter, while $7.3 \%$ strongly disagreed on the subject. Only 1 of the respondents had a conflicted stand on the matter, as shown in table 19 below.

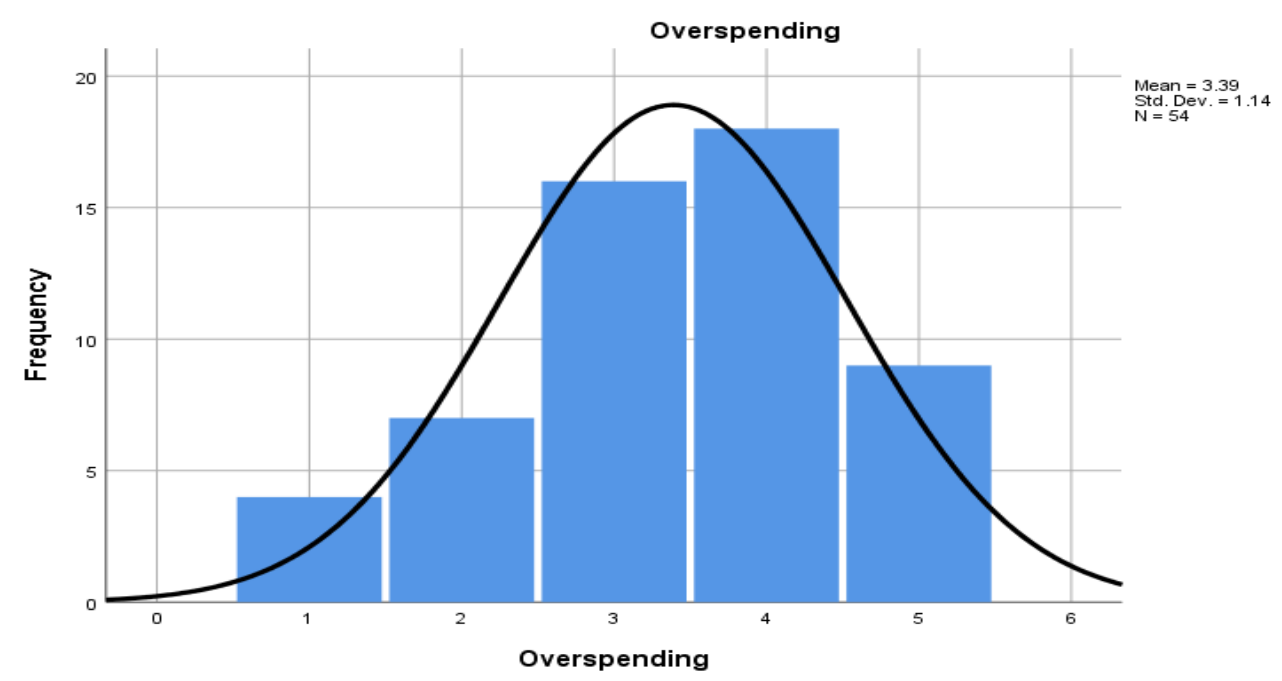

Figure 12: Frequency distribution of contractor's greed of spending contingency

(1-Strongly Disagree, 2-Disagree,3-Neutral, 4-Agree,5-Strongly Agree)

4.3.2 The impact study of the contractor's claim for the commercial berth project in Oman.

\section{Question 20. Payment Delay}


Payment delays have a moderate impact, according to $30.9 \%$ of the respondents. However, $23.6 \%$ of the respondents argue of the slight impact of to the project's completion while $21.8 \%$ provides a conclusion of the high impact the payment delays pose towards a project's completion. $16.4 \%$ of the participants claim that payment delays pose a very high impact while a 5.5\% say it does not impact the project. One of the respondents could not make a valid conclusion, as summarized in table 20 below.

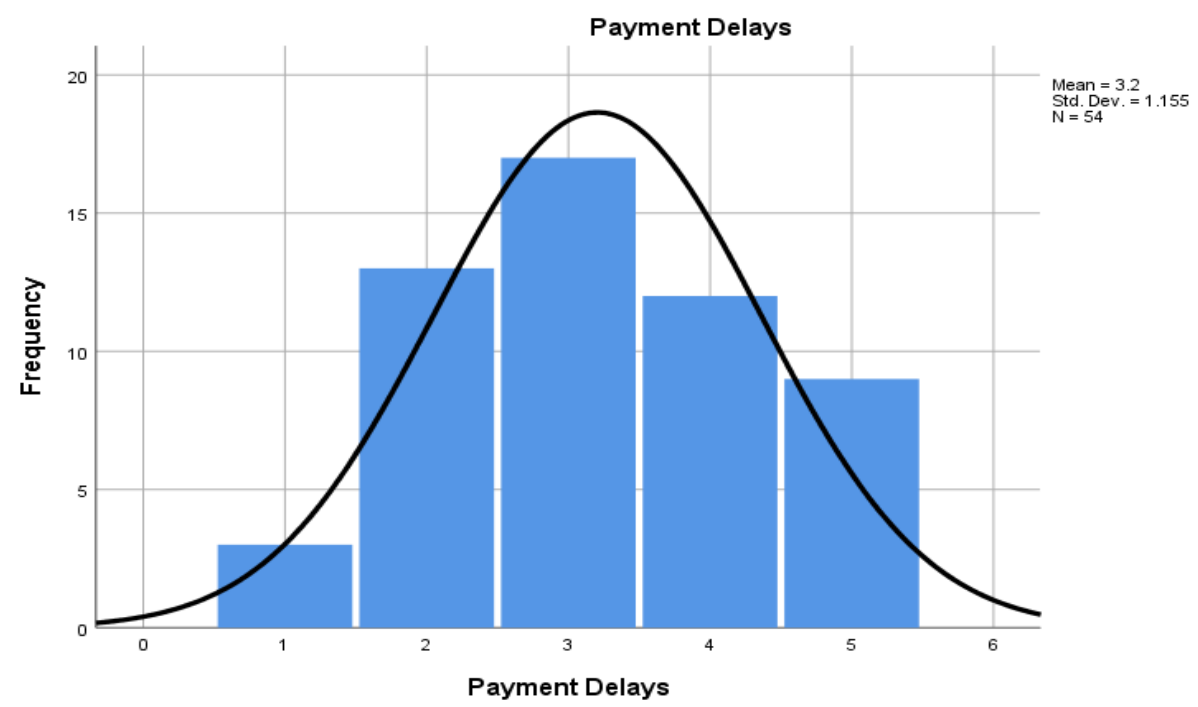

Figure 13: Payment delays affect the completion of the commercial berth projects in Oman.

(1-No Impact, 2-Slight impact, 3-Moderate impact, 4-High impact,5-Very high Impact)

\section{Question 21. Delay extension of time}

$30.9 \%$ of the respondents claim that the time delays have a slight impact to project completion, while $29.1 \%$ claim it has a moderate impact on the project's completion. $20 \%$ claim that it has a high impact on the project's completion, while $16.4 \%$ claim it has a very high impact on the project's completion.

$1.8 \%$ claim that time delays have no impact on the project's success, while one respondent failed to make a valid conclusion about the matter. Table 21 above provides a summary of the impact of time delays on the timely completion of a project. 


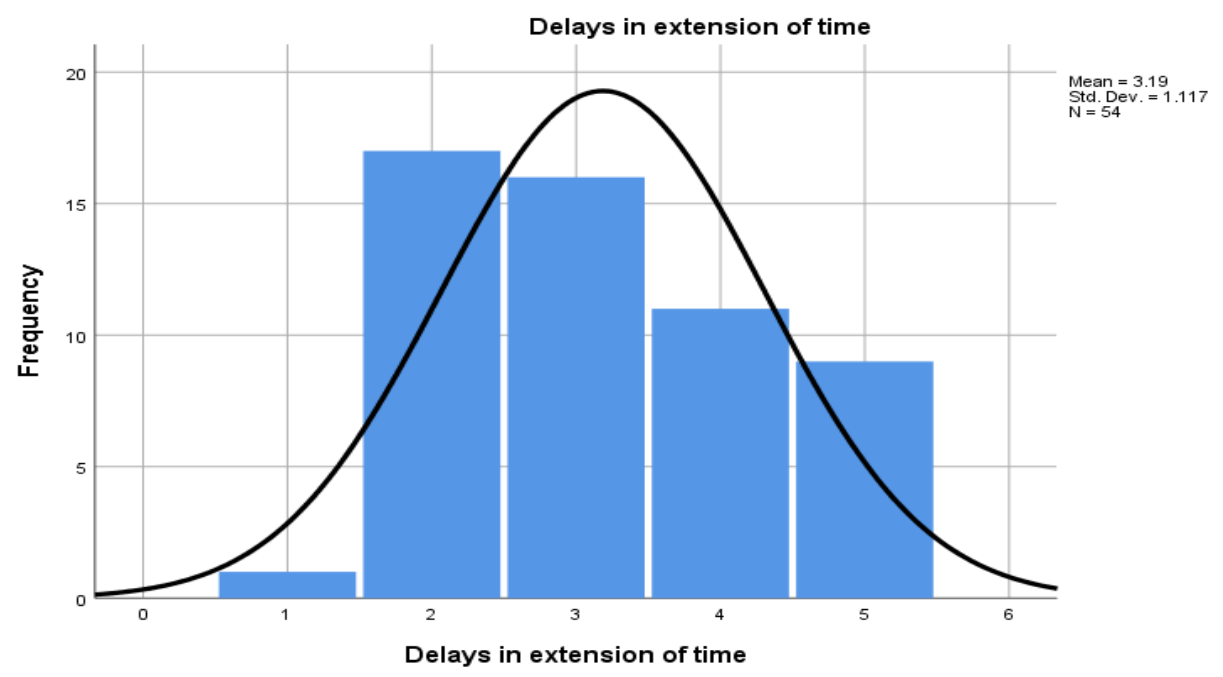

Figure 14: Distribution of the delay in time extensions

(1-No Impact, 2-Slight impact, 3-Moderate impact, 4-High impact,5-Very high Impact)

\section{Question 22. Issuing variation order}

Issuing varying orders has a high impact on the project's completion, according to $36.4 \%$ of respondents. $25.5 \%$ argue of the moderate impact, while $23.6 \%$ argue of the slight impact towards project completion. $14.5 \%$ claim that issuing variation orders has a very high impact on the project's completion. None of the respondents claimed that it has no impact on the project's completion, as identified in table 22 below.

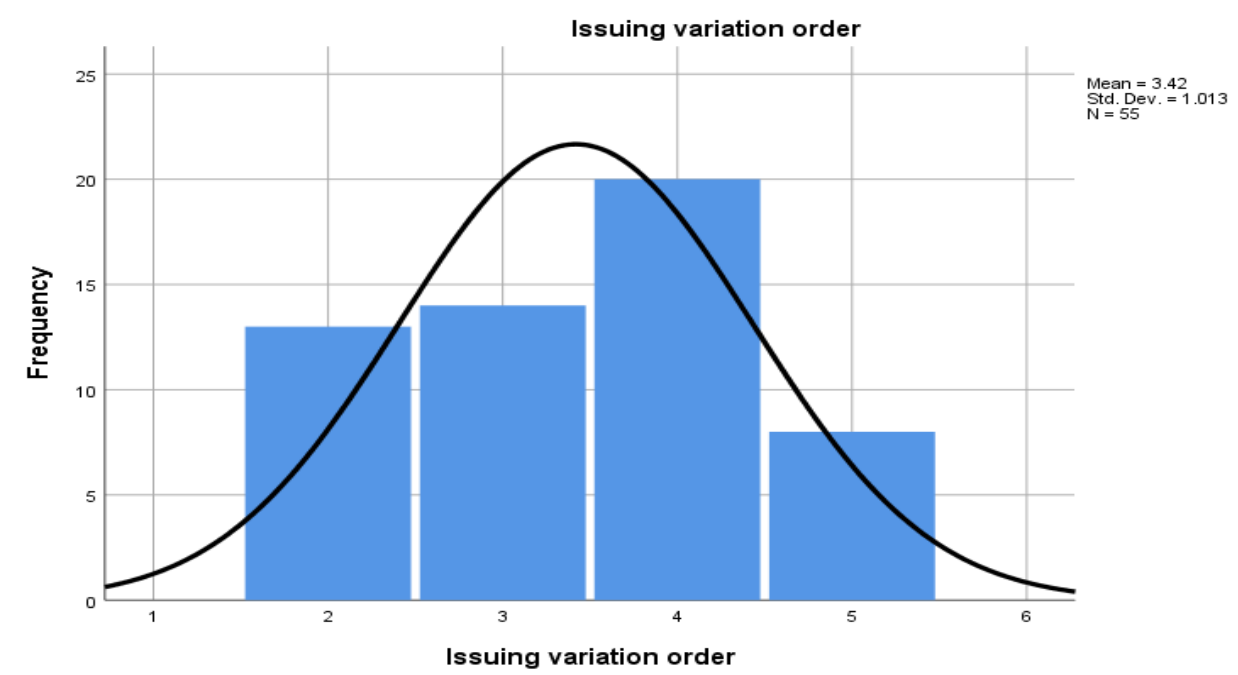

Figure 15: Distribution of the issuing variation order

(1-No Impact, 2-Slight impact, 3-Moderate impact, 4-High impact,5-Very high Impact)

\section{Question 23. Implementing value engineering and cost reduction}


$38.8 \%$ of the respondents claim that value engineering and cost reduction has a slight impact on the project's success. $25.5 \%$ claim it has a moderate impact on project completion. $18.2 \%$ claim that it has a very high impact, $10.9 \%$ claim of its very high impact, $5.5 \%$ argue it has no impact on the value implementation, and cost reduction.

One of the respondents had no claim in the project's implementation of value engineering and cost reduction, as summarized by table 23 above.

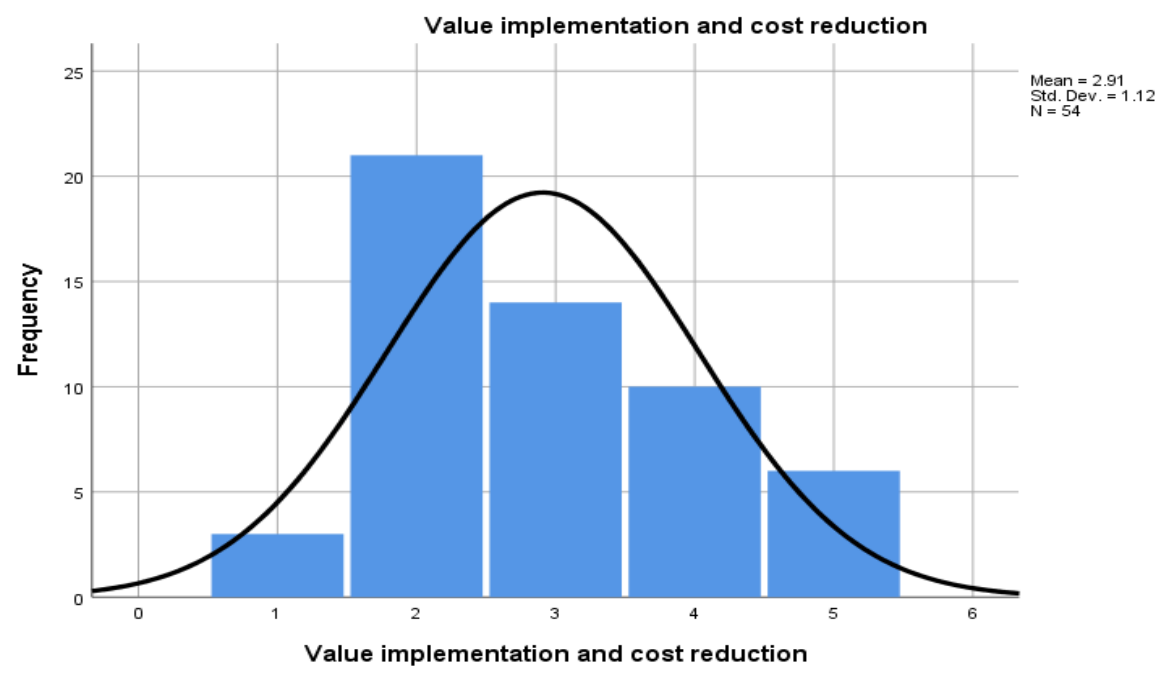

Figure 16: Distribution of implementation and cost reduction

(1-No Impact, 2-Slight impact, 3-Moderate impact, 4-High impact,5-Very high Impact)

\section{Question 24. Low contractor performance}

The low contractor performance has a slight impact on the completion of the project, according to $27.3 \%$ of the respondents. $25.5 \%$ argue it has a high impact, $21.8 \%$ argue it has a moderate impact, and $20 \%$ claim it has a very high impact on the completion of the project. $5.5 \%$ of the project members claim it has no impact on the completion of the project, as illustrated by table 24 below.

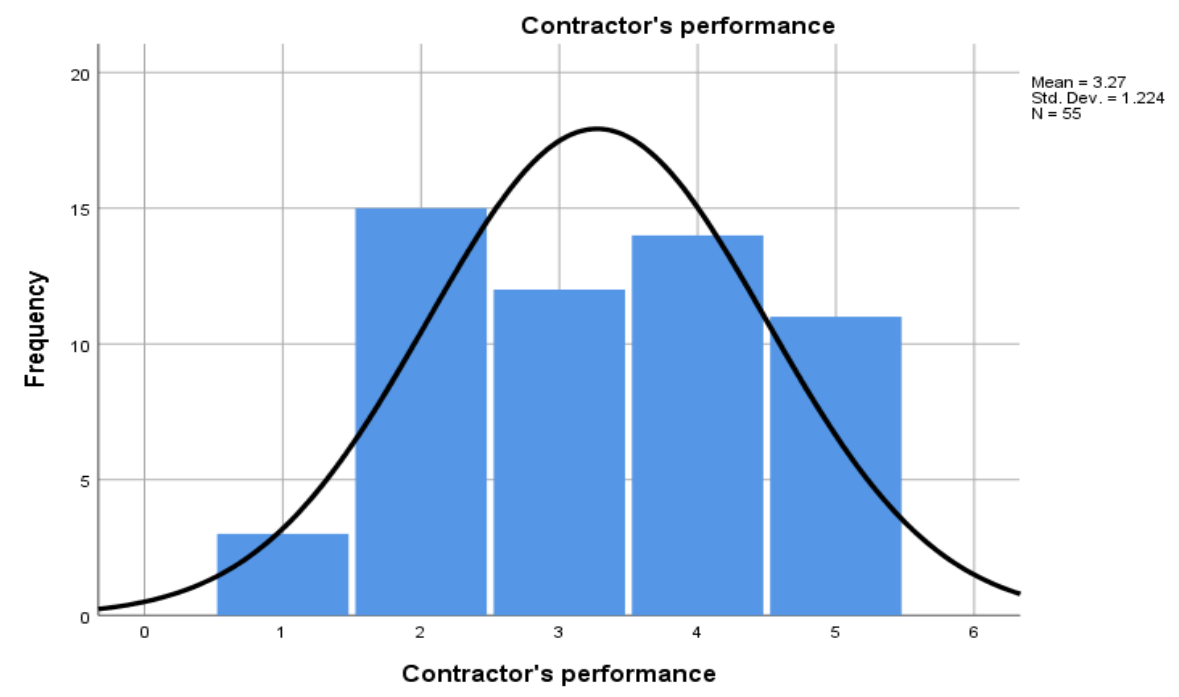

Figure 17: Distribution of the contractor's performance 
(1-No Impact, 2-Slight impact, 3-Moderate impact, 4-High impact,5-Very high Impact)

\section{Conclusion}

\section{Conclusions can be drawn as shown in below:}

Most of the workforce working in the construction sector of Oman are Omani nationals. Many of the people willing to participate in studies in Oman are Omani nationals, with a 90\% occupancy in the workforce within the population study.

The age distribution of the workforce in Oman's construction sector consists of Omanis within the 18 to 45 years old age bracket. Once workers in this sector reach the age of 45 years, most of them tend to leave the industry. This is proven in the presence of $1.8 \%$ of the employees in the workforce above 45 years old.

The majority of the employees working in the construction sector are Bachelor's and Master's degree graduates making up $65.5 \%$ and $30.9 \%$, respectively. This provides information that most of the working sector in construction is educated with very few of the employees, less than $5 \%$, being non-degree holders.

In Duqm port company, the majority of the workers are Engineers with a $72.7 \%$ representation, followed by officer racking up 5.5\% of the total workforce. Teachers represent about $3.6 \%$ of the company's workforce, while other professions make up $16.4 \%$ of the working force in the company.

The construction sector is made up of individuals holding different positions comprising of clients, contractors, supervisors(consultants), and design engineers. Clients are the majority if $45.5 \%$, followed by contractors making up $18.2 \%$, supervisors make up $14.5 \%$ of the total employees, and design engineers sum up $12.7 \%$ of the representation.

The procurement strategy of the represented in the construction sector of Oman differs in variations such as construction management, engineering coupled with procurement and contracting both traditional and non-traditionally cited, traditional procurement, project management, and the traditional view of construction management. The major strategies involved in the procurement strategies in Oman include the use of traditional procurement, taking $36.4 \%$ and engineering, procurement, and contracting with $32.7 \%$.

The majority $(40 \%)$ of the respondents neither disagree nor agree on the weather being a factor contributing claim on the pier project in Oman. However, a significant $32.7 \%$ agree on the weather being a major contributing factor, as illustrated in figure 3 above.

$45.5 \%$ of the respondents agree that the scope of work is a determiner in the selection of the commercial pier project in Oman. Over $60 \%$ of the respondents, as illustrated in figure 4 above, support the scope of work as a determiner while $40 \%$ either disagree or strongly disagree on the scope of work as a determiner.

Most of the respondents consisting of $50.9 \%$ of the total respondents, agree on low prices is a reason behind the selection of the pier project. Only $20 \%$ and $1.8 \%$ percent disagree and strongly disagree respectively on the factor as a contributor.

$52.7 \%$ of the respondents agreed and strongly agreed that the presence of incompetent teams on the site was a major contributor to the selection of the pier project. $23.6 \%$ had a neutral stand on the decision, $20 \%$ disagreed, and $3.6 \%$ strongly disagreed on the factor being a sufficient contributor.

More than half of the respondents, characterized by $18.2 \%$ of the strongly agreeing respondents and $38.2 \%$ of the agreeing candidates, argue that inexperienced staff played a major role in the selection of the pier project, as illustrated in figure 7 above. 
$54.5 \%$ of the respondents agree that the changing requirements are a factor in the determination of the claims to the pier project in Oman. Further, a $21.8 \%$ majority strongly agree with the argument, with only $9.1 \%$ of the respondents disagreeing and strongly disagreeing, and $14.5 \%$ are neutral on the matter.

$36.4 \%$ and $21.8 \%$ of the respondents agree and strongly agree that poor site management is a valid determiner in the selection of the pier project in Oman. $21.5 \%$ are neutral on the matter, while only $20 \%$ do not attribute poor site management as a good factor.

$43.6 \%$ of the respondents agree, while $16.4 \%$ strongly agree on the factor. Therefore, $60 \%$ of the respondents agree that poor coordination is a contributor to the selection of the claims to the commercial project. $14.5 \%$ are neutral, while $16.4 \%$ disagree with only $9.1 \%$ strongly disagreeing on the matter as summarized by figure 10 above.

Many of the respondents making up $45.5 \%$ of the respondents agree that government authorities' delays are a contributing factor, with $16.4 \%$ of the participants strongly agreeing on the matter. Only a significant $20 \%$ disagree, while $18.2 \%$ are neutral on the matter, as summarized in figure 11 above.

$51.1 \%$ of the respondents make up the agreeing majority that the project time frame is a considered factor, with $38.2 \%$ agreeing and $10.9 \%$ strongly agreeing to the matter. $23.6 \%$ of the respondents were neutral on the matter, while $21.8 \%$ disagreed on the matter. Only $3.6 \%$ of the participants strongly disagreed on the matter.

The contractor's overspending contingency factor received a $32.7 \%$ agree to the factor, while only $29.1 \%$ deemed it as a neutral factor. However, $16.4 \%$ of the respondents strongly agree on the factor, while $12.7 \%$ of the respondents disagree on the factor being a contributor. Figure 13 provides a good summary.

$30.9 \%$ of the respondents argue that payment delays have a moderate impact on the completion of projects. However, $23.6 \%$ of the respondents claim that it has a slight impact, while $21.8 \%$ argue of the high impact of the claims. $16.4 \%$ claim that delayed payments have a very high impact on a project's completion.

Time delays have a slight impact on the completion of a project, according to $30.9 \%$ of the respondents. $29.1 \%$ claim of the moderate impact of the factor while $20 \%$ claim that project completion has a high impact on the completion of the project. $16.4 \%$ argue of the high impact the factor poses, as illustrated by figure 15 above.

Issuing varying orders has a high impact according to $36.4 \%$ of the respondents, $25.5 \%$ argue of the moderate impact, $23.6 \%$ argue of the slight impact of the factors. $14.5 \%$ of the respondents claim that varying orders have a very high impact on the completion of the projects.

The contractor's performance has a slight impact, according to $27.3 \%$ of the respondents. $25.5 \%$ argue it has a high impact on the project's completion. $21.8 \%$ of the respondents claim it has a moderate impact on the project's completion, while $20.0 \%$ argue it has a very high impact.

\section{Acknowledgments}

I would like to thank my supervisor, for my research project with my continuous support and encouragement. Also, I would like to express my thanks to Module leader for his support and providing important and relevant advice for this chapter, along with supervisor.

\section{References}

Best, R. and Langston, C. (2006) "Evaluation Of Construction Contractor Performance: A Critical Analysis Of Some Recent Research". Construction Management And Economics 24 (4), 439-445

"Constructions And Frames Meet Language Technology: From The Guest Editors Of The C\&F Special Issue On Frames, Constructions, And Computation" (2014) 6 (1), 1-8 
Middle East College

D. A., V. (1986) "Owner And Contractor Review To Reduce Claims". Journal Of Construction Engineering And Management 112 (1), 104-111

El-Ghrory, A., Bin Tahir, M. and Binti Ismail, N. (2019) "Claim Management Framework Under Fidic 2017: Contractor Claim Submission". Humanities \& Social Sciences Reviews 7 (2), 170-179

Enshassi, A., Choudhry, R. and El-Ghandour, S. (2009) "Contractors' Perception Towards Causes of Claims In Construction Projects". International Journal Of Construction Management 9 (1), 79-92

Goertzen, M.. (2017) 'Introduction to Quantitative Research and Data'. in Applying Quantitative Methods to E-Book Collections. 31

Hai, D. (2019) "Assessment Of Contractors' Claims On Construction Projects In Vietnam". The Open Civil Engineering Journal 13 (1), 218-228

Kim, G. (2019) "A Study On The Improvement Of Construction Claims And Disputes". Korean Journal Of Construction Legal Affairs 5, 1-42.

Lessani, A. (2016) Decision Analysis In Construction Claims. Lessani, Arian

Levander, E., Engström, S., Sardén, Y. and Stehn, L. (2011) "Construction Clients' Ability To Manage Uncertainty And Equivocality". Construction Management And Economics 29 (7), 753-764

Loulakis, M. and McLaughlin, L. (2008) "Government Avoids Liability On Contractor Pass-Through Claim". Civil Engineering Magazine Archive 78 (7), 88-88

Marshall, C. (1969) "Quantification Of Contractor Risk". Naval Research Logistics Quarterly 16 (4), 531-541 Bramble, B. and Callahan, M. (n.d.) Construction Delay Claims.

Mbabazi, A. (2005) Quantification And Analysis Of Construction Claims. Ottawa: National Library of Canada = Bibliothèque nationale du Canada

Mohammed S. Hashem M. Mehany. (2014) "Delay-caused claims in infrastructure projects under design-bid-build delivery systems ". Journal Of Management In Engineering 17 (3), 150-157

Mohsin, M. (2012) "Claim Analysis Of Construction Projects In Oman". International Journal On Advanced Science, Engineering And Information Technology 2 (2), 186

Roopa, S. and Rani, M. (2012) 'Questionnaire Designing for a Survey'. Journal of Indian Orthodontic Society 46 (4_suppl1), 273-277

Sileyew, K.J. (2019) 'Research Design and Methodology'. Intech Open [online] 1 (Cyberspace), 13. available from $<$ https://www.intechopen.com/books/advanced-biometric-technologies/liveness-detection-in-biometrics>

Sibanyama, G., Muya, M. and Kaliba, C. (2012) "An Overview Of Construction Claims: A Case Study Of The Zambian Construction Industry". International Journal Of Construction Management 12 (1), 65-81

SHEN, W., TANG, W., YU, W., DUFFIELD, C., HUI, F., WEI, Y. and FANG, J. (2017) "Causes Of Contractors' Claims In International Engineering-Procurement-Construction Projects". JOURNAL OF CIVIL ENGINEERING AND MANAGEMENT 23 (6), 727-739

Snyder, H. (2019) 'Literature Review as a Research Methodology : An Overview and Guidelines'. Journal of Business Research [online] 104 (August), 333-339. available from <https://doi.org/10.1016/j.jbusres.2019.07.039>

Stone, A. (2018) "Frame Variation In Child Protectionist Claims: Constructions Of Gay Men And Transgender Women As Strangers". Social Forces 97 (3), 1155-1176

Sweet, J. (2004) "Contractor Postcompletion Claims: Advice To Engineers". Journal Of Professional Issues In Engineering Education And Practice 130 (4), 298-303

Vidogah, W. and Ndekugri, I. (1997) "Improving Management Of Claims: Contractors' Perspective". Journal Of Management In Engineering 13 (5), 37-44

Williams, T., Ackermann, F. and Eden, C. (2003) "Structuring A Delay And Disruption Claim: An Application Of Cause-Mapping And System Dynamics". European Journal Of Operational Research 148 (1), 192-204 
Zullo, R. (2011) "RIGHT-TO-WORK LAWS AND FATALITIES IN CONSTRUCTION". Workingusa 14 (2), 225234 